Covered in: Web of Sciences (WOS); EBSCO; ERIH+; Google Scholar; Index Copernicus; Ideas RePeC; Econpapers; Socionet; CEEOL; Ulrich ProQuest; Cabell, Journalseek; Scipio; Philpapers; SHERPA/RoMEO repositories; KVK; WorldCat; CrossRef; CrossCheck

2018, Volume 10, Issue 4, pages: 307-314 | doi: https://doi.org/10.18662/rrem/90

\section{How can}

Inequalities of

Access to Education

be Reduced inside

Mainstream

Education by

Integrating

Elements of the

\section{Private Sector?}

\section{Denis POIZAT ${ }^{\mathbf{1}}$}

${ }^{1}$ Professor at the Université Lyon II

(France), Laboratoire Education, cultures, politiques, denis.poizat@univ-lyon2.fr

\begin{abstract}
In France, for decades, a part of the education of children and teenagers living with a disability was entrusted to the professionals of the private sphere. With the aim of reducing the disparities of access to compulsory education, the French law passed on February 11, 2005, recommends that children living with a disability are schooled in the mainstream State educational system. The number of children with a handicap schooled in ordinary sector amounts to 279,000 in 2016 - against 155,000 at the end of 2006 . Is this important increase correlated to a transformation of the private educational sphere? Was there, during the last decade, an increase of the role of the private sector in the increase of the number of children schooled in mainstream school? We shall analyze the evolution of the private sector input in public education regarding inclusive education at a macro level.
\end{abstract}

Keywords: inequalities; education; mainstream education; private sector.

How to cite: Poizat, D. (2018). How can Inequalities of Access to Education be Reduced Inside Mainstream Education by Integrating Elements of the Private Sector? Revista Romaneasca pentru Educatie Multidimensionala, 10(4), $307-$ 314. https://doi.org/10.18662/rrem/90 
On a micro level, we will also examine a new structure of education embedded into the mainstream pre-schooling system, which contains private elements (managed by the central administration of education, Lyon city council, and a private non-profit organization). This organization is called Unité d'Education Maternelle (U. E. M., Preschool Education Unit) François Truffaut, in Lyon, France. The national social backdrop of this article is crucial, given that we now live in a context of augmentation of prevalence and incidence of some difficulties (dyslexia, dyspraxia, etc.) and an increasing need for recognition of diversity. A lack of vocational and professional training of teachers, as well as a lack of medical schools recently underlined by the Academy of medicine in France represent some of the main aspects of this backdrop. At the same time, the technical and medical resources available in the university hospitals in France allow for the survival of highly premature babies who require a very high level of medical investment many children who would not have survived fifteen years ago live today with, for a big part of this population, specific needs in Education. The new population of the pre-schooling area is changing quite quickly and the question of the private and non-profit sector in education is now crucial.

\section{General aspects of the evolution of school financing in France}

To understand how the education sector is funded in France, we shall rely on the following definition of the Educational Internal Expenses (E.I.E): "E.I.E. collects all the expenses made by all the economic agents (central and local public administrations, companies and households) for educational activities: school and extraschool education of all the levels, the organization of the education system (general administration, orientation, pedagogical documentation, education research, activities intended to favor the school attendance (canteens and boarding schools, school medicine, transport) and expenses asked by institutions (supplies, books, clothing) (INSEE, 2016).

According to the National Institute for Statistics and Economic Studies of France, the State budget dedicated to school funding has globally increased between 1980 and 2015, but was unevenly distributed during this period. It reaches $7.7 \%$ of the Gross Domestic Product (G.D.P.) in 1995, before decreasing to $6.6 \%$ in 2007, and stabilizes at $6.8 \%$ between 2011 and 2015. More specifically, the expense by primary school pupil - which is the level which interests us -- progressed as shows in the graph below (\% GDP):

Educational expenses in France by pupil or student in 2016 
How can Inequalities of Access to Education be Reduced inside Mainstream ...

Denis POIZAT

Dépenses d'éducation par élève ou étudiant en 2016

Dépenses d'éducation par élève ou étudiant en 2016
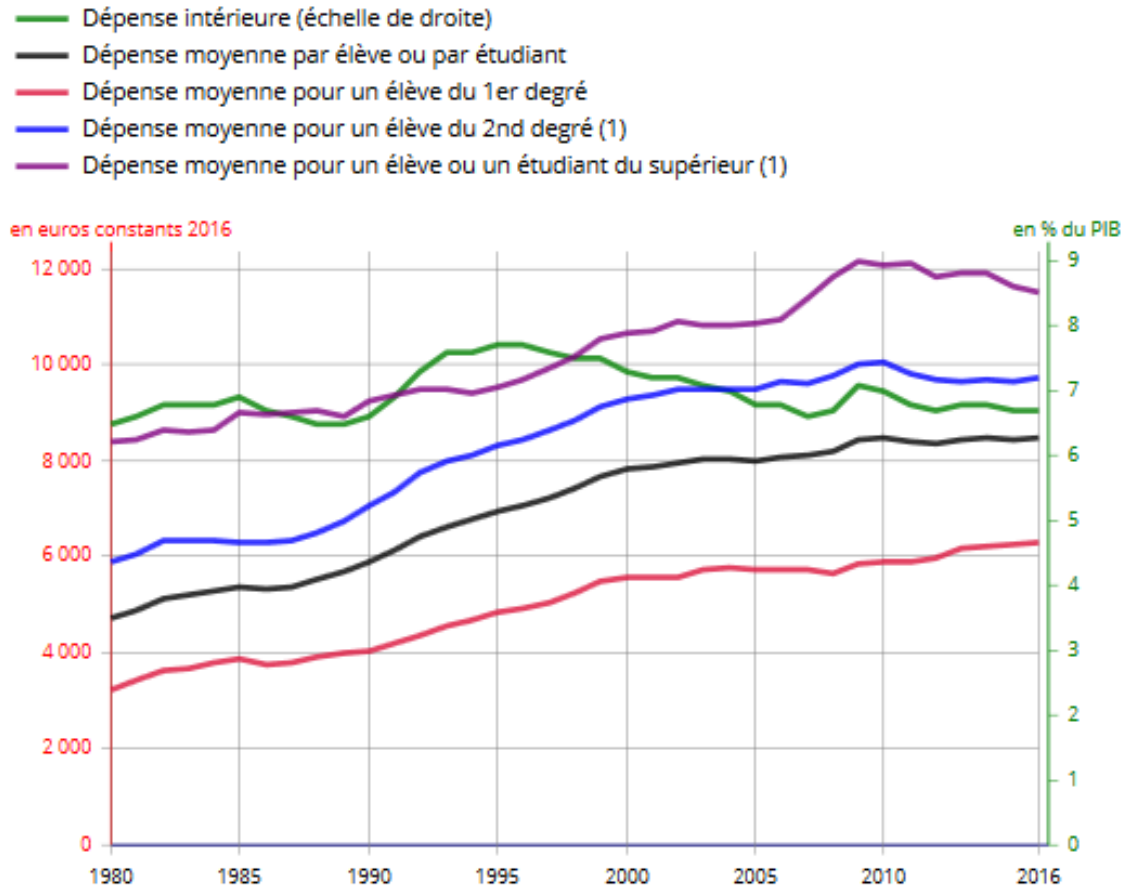

(1) : les séries du second degré et du supérieur incluent l'apprentissage depuis 1999.

Note : le Compte de l'éducation a fait l'objet d'une rénovation en 1999. La réévaluation de la dépense

intérieure d'éducation s'applique à l'ensemble de la période 1980-2016.

Champ : France.

Source : Depo.

The amount of the expense by elementary school pupil subsidized by the State was estimated at 5,720 euros in 2015, against 6,300 euros in 2016 (value 2016).

In France, the 'Compte de l'Éducation' (the French Education Account) was implemented for the first time in 1978, in order to estimate the cost of education in France. Looking at the successive reports from the Comptes de l'Eductation now offers us a retrospective, coherent vision of the satellite account of the education in the national accounting in the last 40 years. However, since 2012, seven years after the law of 2005 demanding that mainstream education include children with a handicap, "the teaching of children living with a disability in primary mainstream schools or in specialized schools is not anymore distinguished from the elementary teaching" within the framework used by the 'Compte de l'Education'. The 
expenses for schooling of the children living with a disability in the primary education level were, according to the terms of the ministry (Ministère de l'éducation nationale, 2016) a "little strong" an estimation. We can therefore consider that the 'Compte de l'Education' does not give an accurate estimation of the public spending in education specifically related to the education for the children with disability or special needs, as opposed to mainstream education. It is not possible to consider if the public funding intended for the schooling of children with particular educational needs was (or not) intended to private actors coming in support of the public system, and in which proportion.

We can however see that, in France, the E.I.E. by pupil increased from 4,680 euros in 1980 to 8440 euros in 2015 - euros value 2015) (INSEE, 2016). The E. I. E intended for private sectors is divided between the expenses intended to the business sector and that of the households, as shown in the picture below:

\section{Internal Expense for education in France}

1. Dépense intérieure d'éducation

\begin{tabular}{lrrrrrr}
\hline & 1980 & 1990 & 2000 & 2010 & 2014 & $2015 p$ \\
\hline Structure du financement initial de la DIE (en \%) & & & & & & \\
État $\quad$ dont : MENESR $^{1}$ & 67,9 & 62,4 & 64,0 & 57,9 & 57,1 & 57,4 \\
Collectivités territoriales & 60,3 & 55,8 & 56,7 & 52,9 & 53,3 & 53,7 \\
Autres administrations publiques et caisses d'allocations familiales & 14,3 & 18,6 & 19,9 & 23,9 & 23,8 & 23,5 \\
Entreprises & 0,4 & 0,8 & 2,2 & 2,3 & 2,8 & 2,8 \\
Ménages & 6,7 & 7,2 & 6,6 & 8,3 & 8,5 & 8,5 \\
Ensemble & 10,7 & 11,0 & 7,3 & 7,6 & 7,8 & 7,8 \\
lat, & $\mathbf{1 0 0 , 0}$ & $\mathbf{1 0 0 , 0}$ & $\mathbf{1 0 0 , 0}$ & $\mathbf{1 0 0 , 0}$ & $\mathbf{1 0 0 , 0}$ & $\mathbf{1 0 0 , 0}$ \\
\hline
\end{tabular}

Whereas households share decreased in 35 years (10.7 \% a $7.8 \%)$, that of the companies slightly increased $(6.7 \%$ to $8.5 \%)$. The public funding of the educational expense was estimated to $82.6 \%$ in 1980, and to $83.7 \%$ in 2015 . This constitutes more than $12 \%$ of the educational expense, which is taken care of by the private sector in 2015 .

If the increase of the number of children with disability is very important between 2005 and 2015, this episode of massive increase of the school demography is not unique in the French educational history: the creation of Sections d'éducation spécialisée (Specialized Education Sections) in the Special Education Secondary schoolsshows an increase of 6533 pupils in 1968-69 to 110524 pupils in 1980-81. This increase is rather comparable to that of the population of children with particular educational needs for a period of one decade approximately (Heurdier, 2016). This mobilization of the public authorities limits itself essentially to the public sector, with little or 
no investment in the private sector. Can we say as much regarding the period 2005-2015?

In France, the State does not fund all of the expenses of social welfares in relation to handicap and dependence. In 2013, the total of these expenses amounted to 59 billion euros. The central State and the local public authorities, the National Instance of Solidarity for the Autonomy ( C.N.S.A) make a financial contribution to this expense, as well as the Social Security Organization (private organization) and the Association de Gestion du Fonds pour l'Insertion Professionnelle des Personnes Handicapées (A.G.E.F.I.P.H.) (also a private organization, but under the supervision of the ministry). In this field, it is difficult to distinguish between the public and private funding.

\section{A Renewal of Experience in the Private-Public Partnership}

The creation of 40 Preeschool Education Units (Unité d'Education Maternelle, U.E.M) for children with autism at the start of the school year on 2014 results from the Autism Plan. It is a national plan of public action 2013-2017 designed to better the living conditions of the people living with an autistic syndrome or an intrusive disorder of development. This public action gave rise to 100 openings of classes at the start of the school year on 2015 in France. The case of the pre-school François Truffaut in Lyon shows how the partnership of the public administration works alongside the private sector. Who is taking part in this plan?

Besides the Ministry of Education, which is the main actor of this U.E.M., the Regional Agency of Health (A.R.S.) $)^{1}$, local sanitary authority representing the State also contribute to the funding of the U. E. M.

The Departmental House of the People with disability (M.D.P.H) ${ }^{2}$, public plan of evaluation and coordination of devices for the disabled people is the second partner. As for the third, it is presented by the authority of the Education in the following way: "the team of supervision of the U.E.M. associates a teacher and medical and social professionals (specialized educators, psychologist, child psychiatrist)" (Academie Lyon, 2015). These are, in this particular case, actors of the private medical and social sector, represented in a federation: the Association for Grown-up and Young Handicapped persons (A.P.A.J.H). It won a tender supplied by the Regional

\footnotetext{
${ }^{1}$ Créées le 1 avril 2010 dans le cadre de la loi Hôpital, patients, santé et territoires du 21 juillet 2009

2 Nées par le titre V de la loi 2005-102 du 11 février 2005 Pour l'égalité des droits et des chances, la participation et la citoyenneté des personnes handicapées
} 
Agency of Health, which funds this association within a public education structure. It is a federation of 92 departmental associations, which manages 650 services and departments and employs 14,000 employees distributed within local antennas.

The composition of the Truffaut Maternal Unit employment scheme shows a very big unbalance in the sharing of jobs between the private sector and the public sector. The Unit counts more than five full-time jobs (5.55) from the private sector: two full-time specialized educators, two full-time educators of young children, a part-time (0.4) psychomotor therapist, a parttime (0.4) psychologist, a part-time (0.5) speech therapist for a total budget of 140,337 euros (year 2016). This pool of professionals from the medical and social sector is managed by a part-time $(\sim 0.25)$ deputy director ${ }^{3}$. The relation between public and private employment is superior to 1 for 5 given that only one teaching full-time position (a specialized teacher) is seconded by the Ministry of Education. The tender system in France allow for such alternative types of partnerships to be taking place within public structures. In this particular tender, the Regional Agency of Health established a precise set of specifications. It considered the bid proposed by the A.P.A.J.H. because the association emphasized the importance of what they call 'including mode' of welcoming of handicapped children within a mainstream environment. Besides, the economic model of the partnership does not support the expenses of taxi to drive the children to the school. It is the children's relatives -- as part of an inclusive way of welcoming children and their into the school - that drive their children to the school themselves.

The use of the Serafin-PH (Services and establishments: reform for an adequacy of the financing to the courses of the disabled people), is indicated as particularly important in the Unit organization. Its aim is to provide a classification of services and acts supplied in order to accurately price them for the service provider used by the medical and social departments within the Unit. The plan is currently in the process of being implemented in France, and has been instigated by National Center of Solidarity for the Autonomy (C.N.S.A) and of the Head office of the social cohesion (D.G.C.S), which took the first initiatives in 2014, then implemented by the State Secretariat with the Prime Minister in charge of disabled people.

The implementation of a principle of pricing of a medical act can be seen to violate a certain form of understanding of the medical and social

\footnotetext{
${ }^{3}$ My thanks go to Martine Pirat Cramet, director of the 'pôle enfance territoire rhodanien', in charge of the François Truffaut U. E. M., for her cooperation and availability.
} 
sector that one would gladly consider as opposed to such practices. France has in fact established a partnership since 2009 with a National Agency of support for the performance - A.N.A.P. (http://www.anap.fr/) devoted to medical and social services. From now on, a national information system of the medical and social establishments covers the whole of France. Will it allow institutions concerned to strengthen the robustness of the budgets assigned to the education of the children or the teenagers with a handicap in ordinary environment or specialized sector? We have yet to know.

\section{The fear of a privatization of the sector of the inclusive education}

Some fear of a privatization of inclusive education have arisen because the pricing in the act can be seen to strongly contradict the implementation of a plan that aims at being at once therapeutic and educational. It can also come in contradiction with the central rule of the French State in the field of public health and education. These debates are not, in fact, new. Health economists and economists of education, therapists, educators, and teachers are well accustomed to such questions. Even if these positions (in regards to the legitimacy of public vs private funding of special need education) have long seen irreconcilable, they seem to be more compatible today; a sign of this is the recent massive approval of the implementation of public/private partnership within circles of educational scholars -- no noisy protest, nor strike. We can wonder, indeed, if the first stage of John Stuart Mill's views on education expressed in On liberty (1859), has in fact already been accepted and achieved. Stuart Mill writes: "If the government made the decision to demand a good education for all the children, he would avoid the punishment to supply with them one. He could leave to the parents the care of having their children educated where and how they wish it, according to the needs for each, and just to pay a part of tuition fees to the poorest children and to cover the fees of those who have nobody else to provide for them. The objections which one set with good reason against the public education do not concern the fact that the State imposes an education, but on the fact that it imposes to supervise it all, which is quite different".

This first stage established by Stuart Mill proposes a partnership with the private sector (which, for the time being, remains non-profit and associative). We can already foresee the service provided by the private sector, already implemented according to a performance classification, could be absorbed or at least penetrated by other private sectors, rather than being restricted to the non-profit private sector only. 


\section{Acknowledgment}

The article has been presented at The XIX ${ }^{\text {th }}$ Congress of the AMSE-AMCEWEAR, 4 - 7 June 2018, Stefan cel Mare University of Suceava, Romania.

\section{References}

Academie Lyon. (2015). Visite de l'Unité d'Enseignement Maternelle pour enfants avec autisme à l'école François Truffaut (Lyon 5ème) [Visit of the Kindergarten Education Unit for children with autism at the François Truffaut School (Lyon 5th)]. Journée internationale des personnes handicapées 2015. Retrieved from http://www.ac-lyon.fr/cid96366/visite-de-l-unite-denseignement-maternelle-pour-enfants-avec-autisme-a-l-ecole-francoistruffaut-lyon-5eme.html

Heurdier , L. (2016). Expansion et transformation de l'enseignement spécial: Le tournant des années 1960. Carrefours de l'éducation, 41(1), 133-149. doi:10.3917/cdle.041.0133

Institut national de la statistique et des etudes economiques (INSEE). (2016). Retrieved from https://www.data.gouv.fr/en/organizations/institutnational-de-la-statistique-et-des-etudes-economiques-insee/

Mill, J. S. (1998). De la liberté [On liberty]. Paris, France: Gallimard.

Ministère de l'éducation nationale. (2016). Le compte de l'éducation, principes, méthodes et résultats pour les années 2006-2014 [Education account, principles, methods and results for the years 2006-2014]. Retrieved from http://cache.media.education.gouv.fr/file/206/59/2/DEPP-dossier-2016206 567592.pdf 